\title{
ANALISIS GAMBARAN KOLABORASI PETUGAS KESEHATAN DALAM PENURUNAN BERAT BADAN PASIEN STROKE ISKEMIK
}

\author{
Nur Wahyuni Munir ${ }^{1)}$, Musfirah Ahmad ${ }^{2)}$ \\ ${ }^{1}$ Fakultas Kesehatan Masyarakat, Universitas Muslim Indonesia \\ nurwahyuni.munir@umi.ac.id \\ ${ }^{2}$ Fakultas Kesehatan Masyarakat, Universitas Muslim Indonesia \\ musfirahmad@gmail.com
}

\begin{abstract}
Stroke is a disorder of local or extensive brain function that occurs suddenly, quickly, and can cause death. Obesity is known as one of the causes of hypertension and stroke. Body Mass Index (BMI) is a simple tool to monitor the nutritional status especially that is related to underweight and overweight status. The purpose of this study was to determine the analysis of the picture of collaboration between health workers in reducing the weight of patients with ischemic stroke in general hospital of Makassar. This research used descriptive design. Samples were taken by purposive sampling with 10 stroke patients who had BMI > 25. This study is conducted by observations and interviews. The instrument used an observation sheet containing demographic data, measurements of blood pressure, weight, and height. Health worker collaboration in reducing stroke patients' weight is more towards health education to patients and families. Health education in the form of a recommended diet such as high fiber, low salt, adequate mineral water intake, and increase physical activity, if there are no contraindications to medical diagnosis by a doctor. Weight loss requires a process and the changes are not immediately visible in a short time, it depending on the length of stay in the hospital, so that consistency in diet and physical activity is needed at home.
\end{abstract}

Keywords: health worker, weight, stroke patients 


\section{PENDAHULUAN}

Stroke adalah gangguan fungsi otak lokal atau ekstensif yang terjadi secara tiba-tiba dan cepat, dapat menyebabkan kematian tanpa penyebab lain kecuali pembuluh darah. Stroke menempati urutan ketiga sebagai penyebab utama kematian di negara berkembang. Berdasarkan patofisiologi stroke iskemik akut, leukosit memainkan peran penting melawan kemunduran dan manifestasi klinis pada pasien dengan melepaskan tiga mediator inflamasi, mekanisme penyambungan dalam mikrosirkulasi, dan vasokonstriksi (Husna, dkk, 2015).

Faktor risiko stroke meliputi risiko yang tidak dapat diubah seperti umur, suku, jenis kelamin, dan genetik. Bila faktor risiko ini ditanggulangi dengan baik, maka kemungkinan mendapatkan stroke dikurangi atau ditangguhkan, makin banyak faktor risiko yang dipunyai makin tinggi pula kemungkinan mendapatkan stroke sedangkan faktor risiko yang dapat diubah merupakan factor risiko terjadinya stroke pada seseorang yang keberadaannya dapat dikendalikan ataupun dihilangkan sama sekali, gaya hidup merupakan tindakan atau perilaku seorang yang biasa dilakukan sehari-hari atau sudah menjadi kebiasaan.

Faktor risiko yang dapat diubah yang memiliki kaitan erat dengan kejadian stroke berulang diantaranya hipertensi, diabetes mellitus, kelainan jantung, kebiasaan merokok, aktifitas fisik/olahraga, kepatuhan kontrol, obesitas, minum alkohol, diet, pengelolaan faktor risiko ini dengan baik akan mencegah terjadinya stroke berulang (Junaidi, 2011).

Jumlah penderita stroke di Indonesia terbanyak dan menduduki urutan pertama di Asia dan ke empat di dunia, setelah India, Cina, dan Amerika. Berdasarkan data dari hasil Riset Kesehatan Dasar 2013, prevalensi stroke di Indonesia berdasarkan diagnosis tenaga kesehatan sebesar 7,0 per mil dan yang berdasarkan diagnosis gejala sebesar 12,1 per mil. Jadi, sebanyak 57,9\% penyakit stroke telah terdiagnosis oleh nakes (Kemenkes RI, 2013).

Prevalensi penyakit stroke meningkat seiring dengan bertambahnya usia, tertinggi pada umur $\geq 75$ tahun $(43,1 \% 94$ dan $67,0 \%)$. Prevalensi stroke yang dijumpai sama tingginya pada laki-laki dan perempuan. Prevalensi stroke cenderung lebih tinggi pada masyarakat dengan pendidikan rendah $(32,8 \%)$. Prevalensi lebih tinggi pada masyarakat yang tidak bekerja (18\%) (Kemenkes RI, 2013).

Menurut Kemenkes RI (2017), disebutkan bahwa dari 10 penyebab kematian utama berdasarkan Sampel Registrasi Sistem (SRS) diantaranya adalah Penyakit Tidak Menular (PTM) yaitu stroke di nomor pertama, urutan kedua penyakit jantung koroner dan ketiga diabetes melitus. Di Indonesia, jumlah penderita stroke tahun 2013 diperkirakan sebanyak 12,1\%. Prevalensi stroke berdasarkan diagnosis nakes dan gejala tertinggi terdapat di Sulawesi Selatan (17,9\%), diikuti Daerah Istimewa Yogyakarta (16,9\%). Prevalensi penyakit stroke tertinggi di Indonesia yaitu Sulawesi Selatan berdasarkan gejala dan diagnosis oleh tenaga kesehatan pada tahun 2007 sebesar 7,4\% dan terjadi peningkatan drastis pada tahun 2013 yaitu 17,9\%. Setelah Sulawesi Selatan yang menjadi urutan kedua yaitu DI Yogyakarta dengan 16,9\% (Kemenkes RI, 2013).

Dari hasil studi pendahuluan yang dilakukan di RSUD Kota Makassar, diperoleh data penyakit stroke hemoragik dan stroke non hemoragik pada bulan Januari-April 2018 didapatkan sebanyak 41 orang dengan presentasi pendarahan intrakranial sebanyak 5 orang dan presentasi infarkserebral 36 orang.

Adapun upaya pencegahan terjadinya stroke yaitu dengan mengendalikan hipertensi, penyakit jantung, diabetes mellitus, hiperkolesterol, obesitas, dan menjauhi rokok, mengkonsumsi alkohol, serta 
menghindari gaya hidup tidak sehat dan stres.

Pada tahun 2014 lebih dari 1,9 milyar orang dewasa yang berumur lebih dari 18 tahun kelebihan berat badan (39\%), dan dari jumlah tersebut 600 juta (13\%) mengalami obesitas (WHO, 2015). Hasil Riset Kesehatan Dasar Indonesia (Riskesdas) tahun 2013, prevalensi obesitas di Indonesia (32,9\%) meningkat dari tahun 2007 (18,1\%). Berdasarkan distribusi lemak, obesitas dibedakan menjadi dua jenis yaitu obesitas sentral dan obesitas umum. Prevalensi obesitas sentral meningkat dari $18,8 \%$ pada tahun 2007 menjadi 26,6\% tahun 2013 (Kemenkes, RI, 2013).

Berdasarkan permasalahan yang diuraikan di atas, penulis merasa tertarik untuk melakukan penelitian mengenai analisis gambaran kolaborasi petugas kesehatan dalam penurunan berat badan pasien stroke iskemik di RSUD Kota Makassar.

\section{METODE}

Penelitian ini dilaksanakan di ruang rawat inap RSUD Kota Makassar dengan rancangan penelitian deskriptif. Populasi dalam penelitian ini adalah semua pasien yang menderita stroke di RSUD Kota Makassar selama bulan Oktober 2018-Maret 2019, yaitu 17 orang. Teknik sampling yang digunakan dalam penelitian ini adalah dengan menggunakan purposive sampling dimana hanya pasien stroke dengan IMT > 25 yang dijadikan sampel penelitian, yaitu 10 orang. Seluruh sampel merupakan stroke iskemik. Adapun instrumen penelitian berupa lembar observasi yang berisi karakteristik responden (inisial nama, jenis kelamin, usia, diagnosa medis, tekanan darah, dan klasifikasi IMT nya).

\section{HASIL DAN PEMBAHASAN}

Tabel 1. Distribusi Responden Berdasarkan Jenis Kelamin, Umur, IMT, Tekanan Darah di RSUD Kota Makassar $2019(\mathrm{n}=10)$

\begin{tabular}{ccc}
\hline & $\mathrm{n}$ & $\%$ \\
\hline JENIS KELAMIN & & \\
Laki-laki & 3 & 30 \\
Perempuan & 7 & 70 \\
\hline UMUR & & \\
45-60 tahun & 8 & 80 \\
$>$ 60 tahun & 2 & 20 \\
\hline IMT & & \\
Gemuk & 9 & 90 \\
Obesitas & 1 & 10 \\
\hline TEKANAN DARAH & & \\
Normal & 1 & 10 \\
Pre Hipertensi & 2 & 20 \\
Hipertensi Stage 1 & 1 & 10 \\
Hipertensi Stage 2 & 6 & 60 \\
\hline
\end{tabular}

Stroke terbagi menjadi 2 kategori yaitu: Stroke Hemoragik dan Stroke Non Hemorahik (Stroke Iskemik). Stroke hemoragik terjadi karena pecahnya pembuluh darah sehingga menghambatan aliran darah yang normal dan darah merembes kedalam suatu daerah otak dan merusaknya. Hampir $70 \%$ khusus stroke hemoragik diderita oleh penderita hipertensi. Pada populasi hanya terdapat satu pasien dengan stroke hemoragik, namun IMT nya < 25 , sehingga tidak memenuhi kriteria inklusi untuk dijadikan sampel penelitian.

Dari 10 responden, semuanya mengalami stroke non hemoragik atau iskemik. Stroke ini terjadi karena tersumbatnya pembuluh darah yang menyebabkan aliran darah ke otak sebagian atau keseluruhan terhenti. Hal ini disebabkan oleh aterosklerosis yaitu penumpukan kolesterol pada dinding pembuluh darah atau bekuan darah yang telah menyumbat suatu pembuluh darah ke otak. Menurut Pudiastuti (2011) hampir sebagian besar pasien mengalami stroke jenis ini, penyumbatan biasa terjadi di 
sepanjang jalur pembuluh darah arteri menuju otak.

\section{Jenis Kelamin}

Dari hasil penelitian menunjukkan bahwa perempuan lebih banyak yang terkena stroke non hemoragik (stroke iskemik) dibandingkan laki-laki yaitu sebanyak $70 \%$. Hal ini tidak sejalan dengan penelitian Nastiti (2012) yang menunjukkan laki-laki sebanyak 376 orang $(60,6 \%)$ lebih banyak yang mengalami stroke dibandingkan perempuan yaitu sebanyak 244 orang (39,4\%). Meski demikian, beberapa penelitian lain juga menunjukkan bahwa perempuan yang lebih banyak terkena stroke. Hal ini menunjukkan bahwa tidak terlihat perbedaan proporsi yang berarti antara penderita laki-laki dengan perempuan.

Umumnya pada stroke akibat penyumbatan aliran darah, penderita lebih banyak dialami wanita. Laki-laki kebanyakan mendeirita stroke akibat perdarahan, yang berkaitan erat dengan aktivitas mereka (Rahmani, 2007). Laki-laki lebih berisiko terkena stroke daripada wanita, tetapi penelitian menyimpulkan bahwa justru lebih banyak wanita yang meninggal karena stroke. Risiko stroke laki-laki 1,25 lebih tinggi daripada wanita, tetapi serangan stroke pada laki-laki terjadi di usia lebih muda sehingga tingkat kelangsungan hidup juga lebih tinggi. Dengan perkataan lain, walau lebih jarang terkena stroke, pada umumnya wanita terserang pada usia lebih tua, sehingga kemungkinan meninggal lebih besar.

\section{Umur}

Hasil penelitian menunjukkan umur 45-60 tahun $80 \%$ lebih banyak dibandingkan usia lansia (> 60 tahun). Sesuai penelitian Dinata (2012), menyatakan bahwa stroke banyak diderita oleh usia $\geq 50$ tahun atau usia tua yaitu sebanyak $81,25 \%$. Orang tua berpotensi terkena stoke dikarenakan adanya perubahan pada jantung terlihat dalam gambaran anatomis berupa bertambahnya kolagen, bertambah ukuran miokard menurut Tamher \& Noorkasiani (2009). Risiko stroke juga meningkat seiring bertambahnya usia, setelah usia 55 tahun risiko meningkat 2 kali lipat setiap kurun waktu 10 tahun. Tetapi, itu tidak berarti bahwa stroke hanya terjadi pada orang lanjut usia karena stroke dapat menyerang semua kelompok umur (Holistic Health Solution, 2011).

IMT (Indeks Massa Tubuh)

Dari hasil penelitian, $90 \%$ mengalami kegemukan dan sisanya obesitas. Menurut WHO, klasifikasi IMT normal 18,5-24,9, kegemukan (overweight) jika IMT nya 2529,9, dan dikatakan obesitas jika IMT nya > $30 \mathrm{~kg} / \mathrm{m}^{2}$. Individu yang mengalami kelebihan berat badan atau obesitas mengalami penurunan yang signifikan dalam harapan hidup. Di samping itu, obesitas juga berkaitan dengan hipertensi, diabetes mellitus, hyperlipidemia, yang semuanya meningkatkan risiko stroke (Ratnasari, 2014)

Indeks Massa Tubuh (IMT) atau Body Mass Index (BMI) merupakan alat atau cara yang sederhana untuk memantau status gizi orang dewasa, khususnya yang berkaitan dengan kekurangan dan kelebihan berat badan. Berat badan kurang dapat meningkatkan risiko terhadap penyakit infeksi, sedangkan berat badan lebih akan meningkatkan risiko terhadap penyakit degeneratif. Oleh karena itu, mempertahankan berat badan normal memungkinkan seseorang dapat mencapai usia harapan hidup yang lebih panjang (Depkes, RI, 2011).

Indeks massa tubuh dihitung sebagai berat badan dalam kilogram $(\mathrm{kg})$ dibagi tinggi badan dalam meter dikuadratkan $\left(\mathrm{m}^{2}\right)$ dan tidak terkait dengan jenis kelamin (Supariasa, 2012). IMT merupakan indikator yang paling sering digunakan dan praktis untuk mengukur tingkat populasi berat badan lebih dan obesitas pada orang dewasa. 
Hipertensi

Dari hasil penelitian, $70 \%$ pasien stroke mengalami hipertensi dan sebanyak $60 \%$ mengalami hipertensi stage 2. Hipertensi (tekanan darah tinggi) merupakan faktor risiko utama yang menyebabkan pengerasan dan penyumbatan arteri. Penderita hipertensi memiliki faktor risiko stroke empat hingga enam kali lipat dibandingkan orang yang tanpa hipertensi dan sekitar 40 hingga 90 persen pasien stroke ternyata menderita hipertensi sebelum terkena stroke.

Klasifikasi tekanan darah, yaitu normal jika $<120 /<80$, pre-hipertensi 120-139/80-89, hipertensi stage 1 140-159/90-99, dan hipertensi stage $2>160 />100$. Secara medis, tekanan darah di atas 140-90 tergolong dalam penyakit hipertensi. Oleh karena dampak hipertensi pada keseluruhan risiko stroke menurun seiring dengan pertambahan umur, pada orang lanjut usia, faktor-faktor lain di luar hipertensi berperan lebih besar terhadap risiko stroke. Pada orang yang tidak menderita hipertensi, risiko stroke meningkat terus hingga usia 90, menyamai risiko stroke pada orang yang menderita hipertensi. Sejumlah penelitian menunjukkan obat-obatan anti hipertensi dapat mengurangi risiko stroke sebesar 38 persen dan pengurangan angka kematian karena stroke sebesar 40 persen.

Terdapat satu responden dengan diabetes mellitus. Penderita diabetes memiliki risiko tiga kali lipat terkena stroke dan mencapai tingkat tertinggi pada usia 50-60 tahun. Setelah itu, risiko tersebut akan menurun. Namun, ada faktor penyebab lain yang dapat memperbesar risiko stroke karena sekitar 40 persen penderita diabetes pada umumnya juga mengidap hipertensi.

Kolaborasi Petugas Kesehatan dalam Penurunan Berat Badan Pasien Stroke

Terapi Diet

Dari hasil penelitian ahli gizi memberikan diet energi sesuai dengan IMT pasien. Diet yang diberikan berupa protein, lemak, dan karbohidrat. Diet diberikan sesuai dengan kondisi pasien, ada yang diberikan secara oral, ada yang menggunakan NGT, diberikan susu formula, bubur saring, makanan lunak, dan diet rendah garam karena sebagian besar menderita hipertensi.

Penyakit stroke berhubungan dengan jenis makanan yang dikonsumsi sehari-hari. Walaupun sebagian orang merasa khawatir akan kadar kolesterol penderita, namun permasalahan utama yang dihadapi seseorang dengan cacat jasmaniah adalah peningkatan berat badan akibat kurang gerak. Disini terjadi suatu lingkaran setan, dimana kenaikan berat

badan membuat penderita akan semakin tidak dapat bergerak dan menaikkan berat badan lagi akan membuat penderita semakin tidak dapat bergerak lagi dan seterusnya (Utami P, 2009 ). Untuk mencegah hal-hal diatas maka terapi diit yang tepat perlu diberikan. Adapun terapi diit yang diberikan adalah sebagai berikut : (1) Memberikan makanan yang cukup nilai gizi untuk mencegah timbulnya stroke ulang; (2) Memberikan makanan yang cukup nilai gizi untuk membantu mempercepat pemulihan kondisi; (3) Memberikan makanan yang disesuaikan dengan faktor resiko penyebab stroke; (4) Membantu menurunkan tekanan darah; (5) Membatasi kolesterol dan lemak, untuk menurunkan kandungan kolesterol/lemak dalam darah; dan (6) Mencegah atau memperlambat komplikasi lebih lanjut.

Adapun syarat diit, yaitu (1) energi: diberikan cukup sesuai umur, tinggi badan, berat badan, jenis kelamin, dan aktivitas; (2) Protein: diberikan cukup $0,8-1 \mathrm{gr} / \mathrm{kg}$ $\mathrm{BB} / \mathrm{hr}$; (3) Lemak: diberikan 20-25\% dari total energi; (4) Karbohidrat: diberikan 6065\% dari total energi; (5) Vitamin: diberikan cukup terutama vit $\mathrm{C}$, vit $\mathrm{B} 6$, vit $\mathrm{E}$, dan vit B12; (6) Mineral: diberikan cukup terutama kalium, $\mathrm{Zn}, \mathrm{Ca}$, dan magnesium; (7) Natrium: diberikan $600-800 \mathrm{mg} /$ hari atau disesuaikan dengan tekanan darah pasien; (8) Serat: diberikan cukup untuk 
menurunkan kolesterol, darah, dan mencegah konstipasi; (9) Cairan: diberikan cukup 6-8 gelas/hr.

Banyak faktor makanan yang berhubungan dengan risiko stroke. Risiko stroke diturunkan dengan mengurangi jumlah asupan lemak (Hooper et al, 2011 dalam Lawrence et al, 2011). Diet yang rendah garam dan kaya dengan sayuran, buahbuahan dan rendah lemak dapat membantu menurunkan tekanan darah. Studi terbaru menunjukkan bahwa peningkatan asupan potassium (misalnya, buah-buahan segar dan sayuran) dapat membantu menurunkan tekanan darah (National Stroke Association, 2013).

Konsumsi serat makanan di Inggris hanya sekitar 32-40 gram/hari per orang, untuk penduduk Asia dan Afrika rata-rata 55-125 gram/hari per orang. Di Amerika disarankan untuk mengkonsumsi serat antara 40-51 gram/hari, serta di Indonesia dianjurkan mengkonsumsi serat antara 20-35 gram/hari. Penambahan konsumsi harus bertahap karena penambahan yang mendadak dapat menyebabkan flatus, kram yang mungkin biasa, pengaruh ini biasanya hanya beberapa hari sampai terjadi adaptasi, dan perlu diingat bila mengkonsumsi banyak serat harus cukup minum.

Fiber atau serat membantu memelihara kesehatan terutama system pencernaan dan mencegah atau mengontrol kejadian penyakit. Umumnya orang membutuhkan serat 27 sampai 40 gram serat setiap hari. Serat yang terbaik biasanya menyertai makanan secara keseluruhan. Serat murni dalam jumlah banyak bisa mempunyai pengaruh yang tidak diinginkan (Syafiq Ahmad, 2007).

Serat makanan mampu mengikat asam empedu, dengan demikian dapat mencegah penyerapannya kembali dari usus, di samping itu juga meningkatkan konversi kolesterol dari darah menjadi asam empedu. Produk akhir pencernaan lemak dalam usus adalah monogliserida, asam lemak, kolesterol, fosfolipid, trigliserida berantai pendek dan medium. Dalam lumen usus halus senyawa tersebut bergantung dengan cairan empedu membentuk agregat yang disebut misel. Lignin dan pectin sebagai penyusun serat makanan mempunyai gugus penukar kation yang mampu mengikat asam empedu dan berfungsi sebagai emulsifier. Dengan demikian kolesterol yang berikatan dengan asam empedu dan lignin/pectin tidak dapat diserap usus, tetapi akan keluar bersama feses.

Aktivitas fisik

Berdasarakan hasil wawancara dengan 3 perawat yang merawat pasien stroke, upaya penurunan berat badan pasien stroke berupa pemberian edukasi kesehatan. Perawat menganjurkan pasien untuk makan makanan berserat, minum air yang cukup, mengurangi konsumsi garam untuk penderita hipertensi, dan melakukan aktivitas fisik, tentunya dengan koordinasi dengan ahli gizi, fisioterapi, dan dokter, sesuai kondisi pasien jika tidak ada kontraindikasi. Perawat mengajarkan Range of Motion (ROM) atau rentang gerak sendi kepada pasien dan keluarga terutama ROM pasif kepada sisi tubuh yang mengalami kelemahan yang dapat dibantu oleh keluarag ketika sudah berada di rumah, dan selama di rumah sakit dapat dibantu oleh perawat atau fisioterapi. Adapun bagian tubuh yang tidak mengalami kelemahan, dapat dilakukan ROM aktif atau dilakukan mandiri secara pasien. Tentunya, akan lebih baik lagi jika pasien mampu berolahraga setiap harinya.

Aktivitas fisik sangat berhubungan dengan dengan faktor risiko, yaitu hipertensi dan aterosklerosis. Seseorang yang sering melakukan aktivitas fisik, minimal 3-5 kali dalam seminggu dengan lama waktu minimal 30-60 menit dapat menurunkan risiko untuk terkena penyakit yang berhubungan dengan pembuluh darah, seperti stroke. Orang yang jarang melakukan aktivitas fisik seperti berolahraga dua kali 
lebih berisiko untuk terkena penyakit jantung koroner, hipertensi, dan hiperlipidemia dibandingkan yang rajin berolahraga, sehingga dianjurkan untuk orang dengan hipertensi dan obesitas untuk berolahraga. Aktivitas fisik dapat membuat lumen pembuluh darah menjadi lebar, sehingga darah dapat melalui pembuluh darah dengan lebih lancar tanpa jantung harus memompa darah lebih kuat.

Dokter memberikan terapi atau medikasi sesuai dengan gejala yang ditimbulkan oleh pasien, seperti pemberian cairan intravena, obat untuk menurunkan tekanan darah bagi yang menderita hipertensi, obat anti nyeri, antibiotik, obat untuk mencegah kerusakan otak, obat untuk menurunkan asam lambung, dan lain-lain.

\section{KESIMPULAN}

Dari hasil observasi dan wawancara dengan dokter, perawat dan ahli gizi, dapat disimpulkan bahwa kolaborasi petugas kesehatan dalam menurunkan berat badan pasien stroke lebih ke arah pendidikan kesehatan kepada pasien dan keluarga. Pendidikan kesehatan berupa diet yang dianjurkan seperti tinggi serat, rendah garam, asupan air mineral yang cukup, dan meningkatkan aktivitas fisik, jika tidak ada kontraindikasi dari diagnosa medis oleh dokter. Penurunan berat badan membutuhkan proses dan tidak langsung terlihat perubahannya dalam waktu singkat, tergantung lamanya hari rawat di rumah sakit. Anjurkan keluarga menggunakan aneka rempah-rempah agar masakan yang diberikan sedikit garam menjadi lebih terasa.

\section{REFERENSI}

1. Depkes, RI. 2011. Petunjuk Teknis Pemantauan Status Gizi Orang Dewasa dengan Indeks Massa Tubuh (IMT). http://www.Landasanteori.com/2018/05/ Pengertian-Indeks-Massa-Tubuh-

Definisi.html. Diakses tanggal $22 \mathrm{Mei}$ 2018.
2. Husna, dkk. 2015. Correlation Between Leukocyte Count When Admitted In Emergency Room (Er) With Clinically Acute Ischemic Stroke Patients.

3. Junaidi. 2011. Stroke waspadai ancaman. (1, Ed.) Yogyakarta: ANDI.

4. Kemenkes, RI. 2013. Badan penelitian dan pengembangan kesehatan. Riset kesehatan dasar.

5. Kemenkes RI. (2017). Profil Kesehatan Indonesia Tahun 2016.

6. Pudiastuti, R. 2011. Penyakit pemicu stroke dilengkapi posyandu lansia dan posbindu PTM. Yogyakarta: Nuha Medika.

7. Supariasa. 2012. Pendidikan dan Konsultasi Gizi. Jakarta: EGC. 